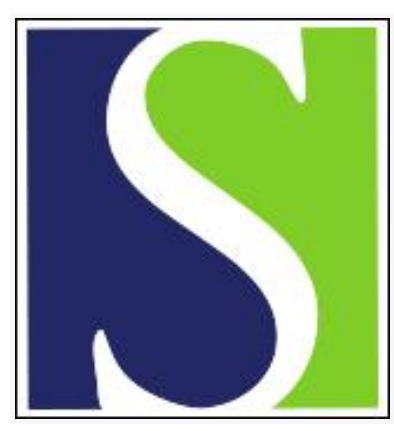

Scand J Work Environ Health 1997;23(4):271-280

https://doi.org/10.5271/sjweh.220

Issue date: Aug 1997

\title{
Chronic bronchitis in farmers
}

by Melbostad E, Wijnand E, Magnus $P$

Key terms: airway obstruction; dust; livestock production; occupational exposure; risk factor; smoking; spouse

This article in PubMed: www.ncbi.nlm.nih.gov/pubmed/9322818

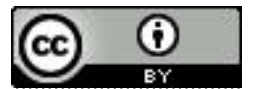




\title{
Chronic bronchitis in farmers
}

\author{
by Erik Melbostad, MD, ${ }^{1}$ Wijnand Eduard, PhD, ${ }^{1}$ Per Magnus MD²
}

\author{
Melbostad E, Wijnand E, Magnus P. Chronic bronchitis in farmers. Scand J Work Environ Health 1997;23(4): \\ $271-80$.
}

\begin{abstract}
Objectives Chronic bronchitis was studied in relation to work time and years of exposure in farming, as well as to production type, dusty occupation outside farming, and the combination of work exposure and smoking, in a population of farmers.

Methods In 1989 a representative cohort of 10792 farmers and spouses was selected from a government register and invited to participate in a cross-sectional study in 1991. The total response rate was $80 \%$. There were $33 \%$ part-time farmers, and among the men $32 \%$ of the full-time and $42 \%$ of the part-time farmers had worked in dusty occupations outside farming. Bronchitis symptoms were recorded on a self-administered questionnaire, spirometric data were obtained, and internal reference equations were calculated for forced expiratory volume in $1 \mathrm{~s}\left(\mathrm{FEV}_{1.0}\right)$.

Results The exposure factors of importance for chronic bronchitis were full-time farming versus part-time farming, livestock production types (poultry, dairy, swine, horse and combinations), and occupational dust exposure outside agriculture. The combinations of the work exposure factors were significant and showed a 2- to 3 -fold increase in risk for chronic bronchitis. Combinations with smoking showed up to a 6-fold increase in risk. Over the age of 50 years, chronic bronchitis was a risk factor for airway obstruction defined as the standardized residuals for $\mathrm{FEV}_{1.0}$ less than -2 for both nonsmokers (OR 2.8, 95\% CI 1.1-6.8) and smokers (OR 8.5, 95\% CI $5.1-14.3)$.

Conclusions Work exposure factors in farming and other dusty occupations enhance the risk for chronic bronchitis from 2- to 3-fold for farmers. In combination with smoking the risk increases to up to 6-fold.
\end{abstract}

Key terms airway obstruction, dust, livestock production, occupational exposure, risk factors, smoking, spouses.

Biological material like grain, animal fodder, and bedding material (eg, wood chips and straw) are potential substrates for the growth of bacteria, molds, and mites. Dust originating from such material may become airborne during different work processes, for example, threshing, milling, foddering, and cleaning $(1-3)$. Immunologically potent substances such as antigens, allergens, endotoxins, glucans, and substances with a complement-stimulating and adjuvant effect have been identified in agricultural dust $(4,5)$. The inhalation of potent irritants provokes inflammatory reactions in the respiratory system and may initiate acute reactions associated with high exposure $(4,5)$. Exposure data relevant to such long-term health effects as chronic bronchitis and airway obstruction are not available.

The prevalence of chronic bronchitis has been assessed in epidemiologic studies of general (6-8), rural (9), and urban populations with questionnaires using modifications of the ATS/MRC definition of chronic bronchitis $(10,11)$. Some general population studies have shown that $30-40 \%$ of the men may have occupational dust exposure associated with chronic bronchitis or "chronic cough" $(6,7,12-14)$. Farmers may have occupational exposure to dust outside agriculture. This possibility may have implications for epidemiologic projects because farmers, like the general population (often used as a reference), may have such exposure of importance.

Studies of the respiratory health of farmers with specialized production (15-18) and a few larger population studies of farmers (19-22) have indicated that dust exposure in agriculture may initiate chronic bronchitis and related symptoms. Exposure assessment in epidemiologic studies of long-term respiratory effects on farming populations have been limited to qualitative indicators of exposure without worktime in farming and exposure outside farming being considered. In the Nordic countries the indoor feeding season is the whole year, with regular exposure in animal tending, whereas plant production is limited to short periods of work and exposure.

1 National Institute of Occupational Health, Oslo, Norway.

2 National Institute of Public Health, Oslo, Norway.

Reprint requests to: Dr Erik Melbostad, National Institute of Occupational Health, PB 8149 Dep, N-0033 Oslo, Norway. 
In our study we have considered the following questions: Is chronic bronchitis in farmers associated with worktime and cumulated exposure time in farming? Are livestock production, dusty occupation outside agriculture, and smoking risk factors for chronic bronchitis in farmers? If so, are there interactions between these factors? In addition, as the role of chronic bronchitis or "cough and phlegm" as a determinant of airway obstruction is controversial, we also considered this question.

\section{Subjects and methods}

Farmers in Norway live on small self-owned family farms in areas with little industrial air pollution. Parttime and full-time farming is common. Only about $10 \%$ of the farms have employees outside the family.

The Norwegian government gives economic support to farmers and regulates and registers the production on farms. We were given access to the government register of farmers so that a representative cohort could be formed of farmers and spouses by the year 1989. In 3 counties of southern Norway 41 farming municipalities were randomly selected. The inclusion criteria were farmers with at least 0.4 human-labor years on the farm, spouses with more than $500 \mathrm{~h}$ of farm work in the year 1989, and eligible persons who had retired in 1986 1989 and were in the age range of 20-67 years ( 69 years by 1991). All the eligible farmers and spouses in these communities, 10792 farmers and spouses in all, were invited to participate in a cross-sectional study during the winter of 1991.

The invited farmers and spouses received a letter with 2 self-administered questionnaires, one on respiratory health and allergy and the other on production, participation in work and work-related symptoms. They were asked to answer the questions at home before they met for examination. If they had problems with the questions they were offered help by a nurse, but few used this possibility.

Spirometry was performed in the sitting position with 4 Vitalograph $S$ volumetric spirometers operated by trained personnel with a protocol according to the recommendations of the American Thoracic Society (23). At least 3 preferably identical FVC curves for forced vital capacity (FVC) (ie, within a variation of $50 \mathrm{ml}$ or maximum $2 \%$ ) were performed. Barometric pressure and spirometer temperature were recorded. The best of the 3 values recorded for forced expiratory volume in $1 \mathrm{~s}$ $\left(\mathrm{FEV}_{1.0}\right)$ corrected for pressure and temperature (BTPS, body temperature, pressure, saturated) were selected for the statistical analysis. Fifty-five persons did not complete the spirometry. Weight and height were measured.
Information from the government's register included type of production, area under cultivation, type and number of animals in production, human-labor years on the farm, the identity of the farmer, and the participation of the spouse in farm work. This information was supplemented by questionnaire data with details on production and the person's participation in different types of work on the farm, part-time and full-time work in agriculture, average workhours per week, number of years in agriculture, retirement, and change in production during the last 10 years. Exposures outside agriculture were registered by questions on dusty work in construction, tunnel work, mining and stone drilling, the smelting industry, paint and plastics work, metal welding and polishing, and work in sawmills.

In general the questions on respiratory symptoms were modified versions from MRC questionnaires used in population surveys in Norway $(7,8)$. Chronic bronchitis was defined as "cough and phlegm 3 months or more per year during the last 2 years". As this definition of chronic bronchitis is not considered very sensitive (4), we added the question: "Do you have cough and phlegm from the chest now?"

The indicators of airway infection were "cough and phlegm in relation to common cold for more than 3-week periods" and "physician or hospital-treated pneumonia or severe bronchitis as an adult".

Questions on smoking habits, previously used for Norwegian populations, were applied (24). Current smokers were defined as daily smokers. Former smokers were defined as persons who had stopped smoking more than 12 months ago. Persons who had been daily smokers and had stopped smoking during the last 12 months were classified as current smokers $(\mathrm{N}=173)$. We also registered grams of tobacco smoked per day and years smoked for former and current smokers.

\section{Statistical methods}

Data analyses were performed with cross-tabulation and multiple logistic regression with "chronic bronchitis" or respiratory symptoms as the dependent variables and exposure variables and personal risk factors as the independent variables, applying SPSS, version 4 (25). Combinations of risk factors were analyzed as nominal variables in cross-tabulation and multiple logistic regression according to principles suggested by Rothmann (26) and principles of model building suggested by Hosmer \& Lemeshow (27). Only the 8482 persons who were met personally were included. Persons with no information on part-time or full-time farming were excluded in the multivariate analysis with workhours as the independent variable (otherwise classified as full-time farming). For the continuous variables, the arithmetic means, standard deviations, standard errors, and $95 \%$ confidence intervals of the groups were calculated. $\mathrm{FEV}_{1.0}$ values were 
analyzed for the men and women, smokers and never smokers separately, with linear regression on height and age. Using the age and height of never smoking men and women, the following internal reference equations for $\mathrm{FEV}_{1.0}$ were calculated in liters per second:

Men: $\quad \mathrm{FEV}_{1.0}$ predicted $=4.615 \times$ height in meters $-0.027 \times$ age $-3.106(\mathrm{SD}=0.648)$

Women: $\mathrm{FEV}_{1.0}$ predicted $=3.956 \times$ height in meters $-0.023 \times$ age $-2.500(\mathrm{SD}=0.551)$

Predicted values, residuals, and standardized residuals were calculated. Standardized residuals of $\mathrm{FEV}_{1.0}$ were analyzed as a continuous variable or categorized as standardized residuals of $\mathrm{FEV}_{1.0}$ of less than -2 ).

In the analysis on cumulative exposure, we applied years in farming, weighted as "years of full-time farming with livestock production" = (age, years -25$) \times(1.5$ for full-time farming $) \times(1.3$ for livestock production $) / 2$.

Lifetime cumulative smoking dose was calculated as pack-years for which the daily smoking dose, $10 \mathrm{~g}$ or less, was classified as $10 \mathrm{~g}$ (half pack) and $11 \mathrm{~g}$ or more as $20 \mathrm{~g}$ (full pack).

\section{Participation in the survey}

The overall primary response rate was $80.8 \%$, including 236 persons (2.2\%) responding by letter only. Altogether,
8482 persons $(78.6 \%, 5568$ men and 2914 women) met for the examination. There were no substantial differences in the age and gender distribution and area under cultivation between all the invited subjects and the respondents, but there was a tendency towards a larger area of production for the respondents than for the nonrespondents (table 1).

Workhours in farming and years of work are shown for the men and women in table 2 . The workhours per week in part-time work were lower for the women (18.6 h) than the men $(24.0 \mathrm{~h})$, and in full-time farming the women had $41.2 \mathrm{~h}$ per week and the men 51.2 per week, respectively. Persons with livestock production had an average of $5 \mathrm{~h}$ longer farm work per week than persons with plant production only. There were no major differences in age, but the women had worked on the farm an average of 5 years less than the men.

\section{Smoking habits}

The prevalence of current smoking among all the participants was $29.8 \%$ (table 2). There was an even distribution of current smokers across age groups, but there were more former smokers in the higher age groups. Among the smokers the average amount of tobacco smoked per day was 12.2 (SD 6.8) g, and the years of smoking averaged 20.6 (SD 11.4).

Table 1. Distribution of the subjects by gender, age, and area under cultivation in different response categories.

\begin{tabular}{|c|c|c|c|c|c|c|c|c|c|}
\hline \multirow{3}{*}{$\begin{array}{l}\text { Response } \\
\text { categories }\end{array}$} & \multicolumn{5}{|c|}{ Gender } & \multicolumn{2}{|c|}{ Age (years) } & \multicolumn{2}{|c|}{ Cultivated area (ha) } \\
\hline & \multicolumn{2}{|c|}{ Men } & \multicolumn{2}{|c|}{ Women } & \multirow[t]{2}{*}{ Al! } & \multirow[t]{2}{*}{ Mean } & \multirow[t]{2}{*}{ SD } & \multirow[t]{2}{*}{ Mean } & \multirow[t]{2}{*}{$\mathrm{SD}$} \\
\hline & N & $\%^{a}$ & $N$ & $\%$ & & & & & \\
\hline $\begin{array}{l}\text { All invited } \\
\text { Met } \\
\text { Answered by letter } \\
\text { Not participated }\end{array}$ & $\begin{array}{r}7135 \\
5568 \\
134 \\
1433\end{array}$ & $\begin{array}{l}66.1 \\
65.6 \\
56.8 \\
69.1\end{array}$ & $\begin{array}{r}3657 \\
2914 \\
102 \\
641\end{array}$ & $\begin{array}{l}33.9 \\
34.4 \\
43.2 \\
30.9\end{array}$ & $\begin{array}{r}10792 \\
8482 \\
236 \\
2074\end{array}$ & $\begin{array}{l}49.0 \\
49.3 \\
46.4 \\
48.0\end{array}$ & $\begin{array}{l}11.1 \\
10.8 \\
11.7 \\
12.0\end{array}$ & $\begin{array}{l}18.0 \\
18.4 \\
17.1 \\
17.1\end{array}$ & $\begin{array}{l}14.3 \\
14.1 \\
14.1 \\
15.3\end{array}$ \\
\hline
\end{tabular}

a Row \%

Table 2. Age, years in agriculture, workhours per week, work exposure outside agriculture, and smoking habits of the men and women in the study.

\begin{tabular}{|c|c|c|c|c|c|c|c|c|c|c|c|c|}
\hline \multirow[t]{2}{*}{ Gendera } & \multirow[t]{2}{*}{ N } & \multicolumn{2}{|c|}{$\begin{array}{c}\text { Age } \\
\text { (years) }\end{array}$} & \multicolumn{2}{|c|}{$\begin{array}{c}\text { Years in } \\
\text { agriculture }\end{array}$} & \multicolumn{2}{|c|}{$\begin{array}{l}\text { Workhours } \\
\text { per week }\end{array}$} & \multicolumn{3}{|c|}{ Smoking (\%) } & \multicolumn{2}{|c|}{$\begin{array}{l}\text { Dust exposure } \\
\text { outside farming }\end{array}$} \\
\hline & & Mean & SD & Mean & $\mathrm{SD}$ & Mean & SD & Never & Current & Former & $N$ & $\%$ \\
\hline \multicolumn{13}{|l|}{ Men } \\
\hline $\begin{array}{l}\text { Part-time farming } \\
\text { Full-time farming } \\
\text { Retired }\end{array}$ & $\begin{array}{r}1423 \\
3722 \\
146\end{array}$ & $\begin{array}{l}47.9 \\
48.6 \\
58.9\end{array}$ & $\begin{array}{l}10.9 \\
11.0 \\
10.5\end{array}$ & $\begin{array}{l}25.3 \\
27.1 \\
36.5\end{array}$ & $\begin{array}{l}14.1 \\
13.9 \\
14.5\end{array}$ & $\begin{array}{l}24.0 \\
52.2\end{array}$ & $\begin{array}{l}16.4 \\
16.0\end{array}$ & $\begin{array}{l}40.5 \\
43.2 \\
26.8\end{array}$ & $\begin{array}{l}30.8 \\
30.0 \\
37.6\end{array}$ & $\begin{array}{l}28.7 \\
26.8 \\
35.6\end{array}$ & $\begin{array}{r}637 \\
1173 \\
47\end{array}$ & $\begin{array}{l}42.3 \\
31.6 \\
29.7\end{array}$ \\
\hline \multicolumn{13}{|l|}{ Women } \\
\hline $\begin{array}{l}\text { Part-time farming } \\
\text { Full-time farming } \\
\text { Retired }\end{array}$ & $\begin{array}{r}1241 \\
1313 \\
178\end{array}$ & $\begin{array}{l}48.5 \\
50.7 \\
56.0\end{array}$ & $\begin{array}{r}10.1 \\
10.1 \\
9.6\end{array}$ & $\begin{array}{l}19.7 \\
22.7 \\
26.7\end{array}$ & $\begin{array}{l}11.3 \\
12.4 \\
12.8\end{array}$ & $\begin{array}{l}18.6 \\
41.2\end{array}$ & $\begin{array}{l}12.1 \\
15.8\end{array}$ & $\begin{array}{l}57.6 \\
54.0 \\
53.0\end{array}$ & $\begin{array}{l}26.6 \\
31.3 \\
32.0\end{array}$ & $\begin{array}{l}15.9 \\
14.7 \\
14.9\end{array}$ & $\begin{array}{r}47 \\
39 \\
8\end{array}$ & $\begin{array}{l}3.9 \\
3.0 \\
4.2\end{array}$ \\
\hline All & 8482 & 49.3 & 10.8 & 25.2 & 13.7 & 40.3 & 20.9 & 46.5 & 29.8 & 23.7 & 1968 & 23.2 \\
\hline
\end{tabular}

a One hundred and seventy-seven men and 182 women had not given information on part-time or full-time farming and were excluded from the table, but the "All" category includes everyone. 


\section{Work exposure outside agriculture}

Altogether 1872 (33.6\%) of the men and 96 (3.3\%) of the women had ever had dusty work outside the farm. Of the men in part-time farming, $42 \%$ had had occupations with dust exposure outside agriculture (table 2). The average employment in such occupations varied from 4.7 years in painting and plastics production to 9.9 years in construction, tunnel, mining and stone drilling work. As some persons had had more than 1 "dusty" occupation in their lives, the mean employment time for such occupations was 9.9 (SD 10.9) years.

\section{Results}

\section{Bronchitis and airway symptoms}

The overall prevalence for "chronic bronchitis" was $8 \%$, and for current cough and phlegm it was $16 \%$. Chronic bronchitis was strongly associated with a positive answer to all "cough and phlegm" questions with odds ratios of 14.7 to 45 , but not so strongly associated with dyspnea and wheezing, odds ratios 2.4 to 10 . "Cough in the morning" and "phlegm from the chest in the morning" were recorded independently and therefore were presented as independent (not exclusive/inclusive) categories.

\section{Risk factors}

Table 3 shows the bivariate associations with the risk factors of full-time farming, livestock production, dust exposure outside agriculture, and current smoking for all the "cough and phlegm" symptom categories and indicators of airway infections. All the outcome categories were significantly associated with livestock production and dust exposure outside agriculture, as well as with current smoking.

Associations between nominal strata of exposure factors (single and combined), smoking, age, and gender as independent variables and "chronic bronchitis" or "cough and phlegm cumulated" as dependent variables are shown in table 4 (reference category: part-time farming with no livestock or dusty occupation outside farming). In table 4 the odds ratios (OR) for chronic bronchitis were more than doubled in all the categories of dust exposure outside farming relative to nonsmoking parttime farming with no livestock.

The overall prevalence of chronic bronchitis was reduced from $8 \%$ to $6.7 \%$ when persons with "asthma as an adult" were excluded, but the same associations with the risk factors were found.

\section{Combinations of exposure factors and smoking}

In a separate analysis the prevalence of chronic bronchitis varied from $2.4 \%$ for never smoking part-time farm-

Table 3. Prevalence of bronchitis symptoms and bivariate associations with risk factors: full-time farming versus part-time farning and livestock production, dusty occupation outside of agriculture and smoking. (OR $=$ odds ratio, $95 \% \mathrm{Cl}=95 \%$ confidence interval)

\begin{tabular}{|c|c|c|c|c|c|c|c|c|c|c|c|c|c|c|c|c|}
\hline \multirow[t]{2}{*}{ Symptoms } & \multicolumn{4}{|c|}{$\begin{array}{l}\text { Full-time versus part- } \\
\text { time farming }\end{array}$} & \multicolumn{4}{|c|}{ Livestock production } & \multicolumn{4}{|c|}{$\begin{array}{l}\text { Dusty occupation } \\
\text { outside of agriculture }\end{array}$} & \multicolumn{4}{|c|}{ Gurrent smoking } \\
\hline & $\begin{array}{c}\text { Part- } \\
\text { time } \\
(\mathrm{N}= \\
2742) \\
(\%)\end{array}$ & $\begin{array}{c}\text { Full- } \\
\text { time } \\
(\mathrm{N}= \\
5025) \\
(\%)\end{array}$ & $\begin{array}{l}\text { Ad- } \\
\text { justeda } \\
\text { OR }\end{array}$ & $95 \% \mathrm{Cl}$ & $\begin{array}{c}\text { No } \\
(\mathrm{N}= \\
1601) \\
(\%)\end{array}$ & $\begin{array}{c}\text { Yes } \\
(\mathbb{N}= \\
6616) \\
(\%)\end{array}$ & $\begin{array}{l}\text { Ad- } \\
\text { justed } \\
\text { OR }\end{array}$ & $95 \% \mathrm{Cl}$ & $\begin{array}{c}\text { No } \\
(\mathrm{N}= \\
5863) \\
(\%)\end{array}$ & $\begin{array}{c}\text { Yes } \\
(N= \\
1904) \\
(\%)\end{array}$ & $\begin{array}{l}\mathrm{Ad}^{-} \\
\text {justed } \\
\text { OR }\end{array}$ & $95 \% \mathrm{Cl}$ & $\begin{array}{l}\text { No } \\
\langle \%\rangle\end{array}$ & $\begin{array}{l}\text { Yes } \\
(\%)\end{array}$ & $\begin{array}{l}\text { Ad- } \\
\text { justed } \\
\text { OR }\end{array}$ & $95 \% \mathrm{Cl}$ \\
\hline $\begin{array}{l}\text { Chronic } \\
\text { bronchitis }\end{array}$ & 6.5 & 8.8 & 1.29 & $1.06-1.57$ & 6.4 & 8.4 & 1.29 & $1.03-1.63$ & 7.3 & 10.1 & 1.31 & $1.08-1.59$ & 5.8 & 13.5 & 2.53 & $2.13-2.99$ \\
\hline Chronic cough & 5.4 & 7.0 & 1.23 & $1.00-1.52$ & 5.5 & 6.7 & 1.28 & $1.00-1.58$ & 5.8 & 8.6 & 1.34 & $1.08-1.66$ & 4.2 & 12.3 & 3.25 & $2.71-3.92$ \\
\hline now & 13.2 & 17.3 & 1.30 & $1.12-1.49$ & 12.9 & 16.6 & 1.27 & $1.07--1.50$ & 15.0 & 18.5 & 1.24 & $1.07-1.44$ & 11.9 & 25.9 & 2.60 & $2.28-2.89$ \\
\hline $\begin{array}{l}\text { Cough in the } \\
\text { morning }\end{array}$ & 8.9 & 12.3 & 1.24 & $1.03-1.48$ & 9.6 & 11.5 & 1.21 & $1.0-1.47$ & 10.1 & 14.1 & 1.29 & $1.08-1.30$ & 5.3 & 25.5 & 6.27 & $5.37-7.27$ \\
\hline $\begin{array}{l}\text { Phlegm from chest } \\
\text { (morning) }\end{array}$ & 9.1 & 11.0 & 1.09 & $0.92-1.30$ & 8.7 & 10.8 & 1.30 & $1.06-1.59$ & 9.2 & 13.9 & 1.38 & $1.16-11.64$ & 6.7 & 19.5 & 3.40 & $2.92-3.95$ \\
\hline Cough during the day & 7.3 & 10.0 & 1.28 & $1.07-1.53$ & 8.1 & 9.3 & 1.15 & $0.93-1.41$ & 8.2 & 11.7 & 1.36 & $1.13-1.63$ & 6.2 & 16.0 & 2.93 & $2.49-3.43$ \\
\hline $\begin{array}{l}\text { Cough and phlegm } \\
\text { cumulated, all cases }\end{array}$ & 22.6 & 28.1 & 1.31 & $1.13-1.47$ & 22.6 & 27.1 & 1.24 & $1.05-1.42$ & 24.2 & 32.4 & 1.42 & $1.25-1.61$ & 19.5 & 43.1 & 3.26 & $2.71-3.92$ \\
\hline Airway infections & & & & & & & & & & & & & & & & \\
\hline $\begin{array}{l}\text { Chest cold with } \\
\text { cough and phlegm } \\
\text { for more than } 3 \text { weeks } \\
\text { and more than } \\
1 \text { period during the } \\
\text { last } 2 \text { years }\end{array}$ & 11.3 & 12.5 & 1.17 & $0.99-1.37$ & 10.2 & 12.5 & 1.23 & $1.02-1.48$ & 11.1 & 15.0 & 1.41 & $1.20-1.67$ & 10.4 & 16.5 & 1.65 & $1.43-1.91$ \\
\hline $\begin{array}{l}\text { Hospital or physician- } \\
\text { treated bronchitis or } \\
\text { pneumonia }\end{array}$ & 13.7 & 13.0 & 0.92 & $0.79-1.06$ & 11.0 & 13.8 & 1.32 & $1.10-1.58$ & 12.7 & 14.9 & 1.25 & $1.06-1.47$ & 12.5 & 15.7 & 1.34 & $1.16-1.55$ \\
\hline
\end{tabular}

a The $O R$ for the risk factors was adjusted for age and gender.

b Chronic bronchitis: cough and phlegm 3 months or more per year during the last 2 years. 
ers with no livestock and without dust exposure outside farming to $14.6 \%$ for ever smoking full-time farmers with past or present dust exposure outside farming (not tabulated). For the never smokers the adjusted odds ratio for chronic bronchitis with part-time livestock production was 2.17 (95\% CI 1.001-4.70) and for full-time farming with livestock it was $2.75(95 \%$ CI $1.33-5.72)$ relative to part-time farming with no livestock or dust exposure outside farming. With full-time farming, livestock production and smoking and dust outside farming combined, the odds ratio for chronic bronchitis was 6.37 (95\% CI 3.0-13.6), adjusted for all risk factors, age, gender, and change in production.

The effect of livestock separately and in combination with smoking is shown table 5, from which persons with dust exposure outside farming were excluded. The adjusted odds ratio was 1.77 (95\% CI $1.18-2.67)$ for livestock, 2.12 (95\% CI 1.34-3.34) for ever smoking, and $2.72(95 \%$ CI $1.83-4.05)$ for the combination of livestock and smoking; this result indicates independent ef-

Table 4. Chronic bronchitis and cough and phlegm cumulated in relation to combination of work exposure factors and also to other risk factors. (OR = odds ratio, $95 \% \mathrm{Cl}=95 \%$ confidence interval)

\begin{tabular}{|c|c|c|c|c|c|c|c|}
\hline \multirow[t]{2}{*}{ Risk factors } & \multirow{2}{*}{$\begin{array}{c}\text { Number } \\
\text { of } \\
\text { subjects }\end{array}$} & \multicolumn{3}{|c|}{ Chronic bronchitis } & \multicolumn{3}{|c|}{$\begin{array}{l}\text { Cough and phlegm } \\
\text { cumulated }\end{array}$} \\
\hline & & $\%$ & Adjusted $0 \mathrm{R}^{b}$ & $95 \% \mathrm{Cl}$ & $\%$ & Adjusted OR & $95 \% \mathrm{Cl}$ \\
\hline \multicolumn{8}{|c|}{$\begin{array}{l}\text { Work factors in combinations } \\
\text { No dust outside farming }\end{array}$} \\
\hline \multirow{2}{*}{\multicolumn{8}{|c|}{$\begin{array}{l}\text { No dust outside farming } \\
\text { Part-time farming }\end{array}$}} \\
\hline & & & & & & & \\
\hline No livestock & 594 & 4.4 & 1 & & 16.7 & 1 & \\
\hline Livestock & 1458 & 6.4 & 1.52 & $0.97-2.39$ & 22.1 & 1.42 & $1.10-1.82$ \\
\hline \multicolumn{8}{|l|}{ Full-time farming } \\
\hline No livestock & 580 & 5.9 & 1.22 & $0.72-2.08$ & 22.6 & 1.37 & $1.02-1.84$ \\
\hline Livestock & 3231 & 8.4 & 1.99 & $1.31-3.01$ & 26.7 & 1.80 & $1.42-2.27$ \\
\hline \multicolumn{8}{|c|}{ Dust outside farming } \\
\hline \multicolumn{8}{|c|}{ Part-time farming } \\
\hline $\begin{array}{l}\text { No livestock } \\
\text { Livestock }\end{array}$ & $\begin{array}{l}247 \\
443\end{array}$ & $\begin{array}{r}10.1 \\
7.4\end{array}$ & $\begin{array}{l}2.27 \\
1.59\end{array}$ & $\begin{array}{l}1.27-4.05 \\
0.94-2.73\end{array}$ & $\begin{array}{l}27.1 \\
30.0\end{array}$ & $\begin{array}{l}1.73 \\
1.93\end{array}$ & $\begin{array}{l}1.20-2.49 \\
1.42-2.61\end{array}$ \\
\hline \multicolumn{8}{|l|}{ Full-time farming } \\
\hline $\begin{array}{l}\text { No livestock } \\
\text { Livestock }\end{array}$ & $\begin{array}{r}180 \\
1034\end{array}$ & $\begin{array}{l}10.0 \\
11.2\end{array}$ & $\begin{array}{l}2.16 \\
2.48\end{array}$ & $\begin{array}{l}1.15-4.08 \\
1.59-3.88\end{array}$ & $\begin{array}{l}36.1 \\
33.9\end{array}$ & $\begin{array}{l}2.56 \\
2.33\end{array}$ & $\begin{array}{l}1.75-3.75 \\
1.80-3.02\end{array}$ \\
\hline \multicolumn{8}{|l|}{ Other factors } \\
\hline \multicolumn{8}{|c|}{ Change in production } \\
\hline No & 7664 & 7.8 & 1 & & 25.1 & 1 & \\
\hline Yes & 103 & 20.4 & 3.27 & $2.01-5.34$ & 44.7 & 2.32 & $1.55-3.47$ \\
\hline \multicolumn{8}{|l|}{ Smoking } \\
\hline Never & 3739 & 5.6 & 1 & & 18.4 & 1 & \\
\hline Ever & 4028 & 10.2 & 1.81 & $1.50-2.16$ & 33.3 & 2.13 & $1.92-2.38$ \\
\hline \multicolumn{8}{|l|}{ Gender } \\
\hline $\begin{array}{l}\text { Male } \\
\text { Female }\end{array}$ & $\begin{array}{l}5235 \\
2532\end{array}$ & $\begin{array}{l}8.6 \\
6.7\end{array}$ & $\begin{array}{l}1.07 \\
1\end{array}$ & $0.88-1.32$ & $\begin{array}{l}27.5 \\
23.3\end{array}$ & $\begin{array}{l}0.99 \\
1\end{array}$ & $0.98-1.12$ \\
\hline
\end{tabular}

a Total number of subjects $=7767$ (715 persons with no information on part-time or full-time farming were excluded from the analysis).

b Adjusted OR for all factors in the table and age by logistic regression. Reference category of work exposure: part-time farming with no livestock.

Table 5. Prevalence of chronic bronchitis according to smoking among the subjects. (OR = odds ratio, $95 \% \mathrm{Cl}=95 \%$ confidence interval)

\begin{tabular}{|c|c|c|c|c|c|c|c|c|}
\hline \multirow[t]{3}{*}{ Variable } & \multicolumn{4}{|c|}{ Never smokers } & \multicolumn{4}{|c|}{ Ever smokers } \\
\hline & \multirow[t]{2}{*}{$N$} & \multicolumn{3}{|c|}{ Chronic bronchitis } & \multirow[t]{2}{*}{ N } & \multicolumn{3}{|c|}{ Chronic bronchitis } \\
\hline & & $\%$ & OR & $95 \% \mathrm{Cl}$ & & $\%$ & $\mathrm{OR}$ & $95 \% \mathrm{Cl}$ \\
\hline \multicolumn{9}{|l|}{$\begin{array}{l}\text { No dust outside } \\
\text { farming (N = 6514) }\end{array}$} \\
\hline $\begin{array}{l}\text { No livestock } \\
\text { Livestock }\end{array}$ & $\begin{array}{r}798 \\
2542\end{array}$ & $\begin{array}{l}3.6 \\
6.2\end{array}$ & $\begin{array}{l}1 \\
1.77\end{array}$ & $1.18-2.67$ & $\begin{array}{r}777 \\
2397\end{array}$ & $\begin{array}{l}8.1 \\
9.6\end{array}$ & $\begin{array}{l}2.12 \\
2.72\end{array}$ & $\begin{array}{l}1.34-3.34 \\
1.83-4.05\end{array}$ \\
\hline \multicolumn{9}{|l|}{ No livestock ( $N=2043$ ) } \\
\hline $\begin{array}{l}\text { No dust } \\
\text { Dust outside farming }\end{array}$ & $\begin{array}{l}798 \\
180\end{array}$ & $\begin{array}{l}3.6 \\
5.6\end{array}$ & $\begin{array}{l}1 \\
1.67\end{array}$ & $0.78-3.58$ & $\begin{array}{l}777 \\
288\end{array}$ & $\begin{array}{r}8.1 \\
12.8\end{array}$ & $\begin{array}{l}2.13 \\
3.87\end{array}$ & $\begin{array}{l}1.35-3.38 \\
2.25-6.66\end{array}$ \\
\hline
\end{tabular}


fects of the 2 factors. However, when smoking and dust exposure outside agriculture were studied for persons without livestock (table 5), the adjusted odds ratio was $1.67(95 \%$ Cl $0.78-3.58)$ for "dust", $2.13(95 \% \mathrm{CI}$ 1.35-3.38) for "ever smoking", and 3.87 (95\% Cr 2.25-6.66) for the combination "ever smoking" and "dust". This finding indicates an interaction between the exposure factors "dust outside farming" and "ever smoking".

\section{Different production types}

The prevalences of chronic bronchitis and associations with different types and combinations of livestock production relative to part-time, no livestock (reference $O R=1)$ are shown for the never smoking persons with no work exposure outside farming $(\mathbb{N}=3340)$ in table 6 . Elevated odds ratios were found for all the livestock production types, most in poultry production (OR 5.05, $95 \% \mathrm{Cl} 2.33-11.0$ ) and combinations with cow and horse, swine and sheep or goat. In the smallest groups with the lowest prevalences the odds ratios were not significant.

On the average, $1-1.5 \%$ of the farmers in each 10 year age group changed production due to dust nuisance during the last 10 years. Change in production (adjusted OR 3.27, 95\% CI 2.01-5.34) and retirement (adjusted OR $2.2,95 \%$ CI $1.6-3.2$ ) was significantly associated with chronic bronchitis. The impact of retirement and change in production on the crude odds ratio for livestock was calculated. With the observed retirement of about 100 persons annually in 25 years (the average time of occupation in agriculture) and the observed $12 \%$ prevalence of chronic bronchitis among the retired, of

Table 6. Chronic bronchitis in relation to production type, $\mathrm{N}=3340 .^{\text {a }}(\mathrm{OR}=$ odds ratio, $95 \% \mathrm{Cl}=95 \%$ confidence interval)

\begin{tabular}{|c|c|c|c|c|}
\hline \multirow[t]{2}{*}{ Categories of production } & \multirow{2}{*}{$\begin{array}{l}\text { Number } \\
\text { of } \\
\text { subjects }\end{array}$} & \multicolumn{3}{|c|}{ Chronic bronchitis } \\
\hline & & $\%$ & $\begin{array}{c}\text { Adjusted } \\
\mathrm{OR}^{\mathrm{b}}\end{array}$ & $95 \% \mathrm{Cl}$ \\
\hline \multicolumn{5}{|l|}{ No livestock } \\
\hline $\begin{array}{l}\text { Part-time (reference) } \\
\text { Full-time }\end{array}$ & $\begin{array}{l}517 \\
281\end{array}$ & $\begin{array}{l}3.1 \\
4.6\end{array}$ & 1.51 & $0.68-3.35$ \\
\hline \multicolumn{5}{|l|}{ Livestock } \\
\hline $\begin{array}{l}\text { Swine } \\
\text { Poultry } \\
\text { Sheep or goat } \\
\text { Cow or dairy }\end{array}$ & $\begin{array}{r}239 \\
106 \\
259 \\
1013\end{array}$ & $\begin{array}{r}5.0 \\
13.2 \\
5.4 \\
5.1\end{array}$ & $\begin{array}{l}1.76 \\
5.05 \\
2.04 \\
1.81\end{array}$ & $\begin{array}{l}0.80-3.85 \\
2.33-11.0 \\
0.97-4.31 \\
0.99-3.33\end{array}$ \\
\hline \multicolumn{5}{|l|}{ Combinations of livestock } \\
\hline $\begin{array}{l}\text { Cow and horse } \\
\text { Cow and swine } \\
\text { Cow, sheep and goat } \\
\text { Cow and poultry } \\
\text { Other combinations }\end{array}$ & $\begin{array}{r}72 \\
236 \\
271 \\
170 \\
176\end{array}$ & $\begin{array}{r}13.9 \\
8.1 \\
6.6 \\
6.5 \\
4.0\end{array}$ & $\begin{array}{l}5.41 \\
2.74 \\
2.40 \\
1.76 \\
1.41\end{array}$ & $\begin{array}{l}2.29-12.8 \\
0.72-5.58 \\
1.16-4.94 \\
0.95-4.83 \\
0.56-3.55\end{array}$ \\
\hline
\end{tabular}

a Persons with dust exposure outside farming or smoking or both excluded.

- Adjustment factors: age, gender, work time, change in production and retirement. which $70 \%$ had livestock production, the crude odds ratio for livestock production would have changed from 1.25 to 1.40

A change in production because of dust nuisance during the last 10 years was reported by 111 persons and 23 persons with chronic bronchitis, of which 8 no longer had livestock.

Adjustment for this factor would change the crude odds ratio from 1.25 to 1.34 , and after 25 years it would be 1.51 .

\section{Gender and age}

When workhours, age, and production were taken into consideration, there was no significant difference between the men and women (OR 1.0).

Age was correlated with years in agriculture $(r=0.77$, $P<0.001)$. There was a significant effect of years of age on the risk of chronic bronchitis (OR 1.01, 95\% CI $1.004-1.02$ )

\section{Cumulative exposure indicators}

We applied cumulative exposure indicators in logistic regression models to determine the effects of exposure cumulated over a lifetime on chronic bronchitis. In all $(N=8482)$ the adjusted odds ratio per pack-year of smoking was 1.038 (95\% Cl 1.032-1.105), and for per year of farming weighted as full-time with livestock it was 1.008 (95\% CI 0.928-1.095). For the never smokers $(\mathrm{N}=4080)$ the adjusted odds ratio for chronic bronchitis per year of farming weighted as full-time with livestock was 1.025 (95\% CI 1.012-1.038). The odds ratios were adjusted for gender and dusty occupation outside farming. Years of dust exposure outside farming did not show any significant effect.

\section{Airway obstruction}

Table 7 presents the results for airway obstruction. Standardized residuals of $\mathrm{FEV}_{1.0}$ near the "predicted" (ideally mean 0.000 ) were found for the never smokers ("all" and without "cough and phlegm"), with significant reduction in all the smoking and symptom groups, except for chronic bronchitis among the never smokers, when asthma was excluded (mean standardized residuals of $\mathrm{FEV}_{1.0}$ $0.008,95 \%$ CI -0.022 to +0.038 ); whereas the same group of ever smokers had mean standardized residuals of $\mathrm{FEV}_{1.0}$ of $-0.410(95 \% \mathrm{Cl}-0.519$ to -0.300$)$, which indicated airway obstruction.

Airway obstruction in subjects with bronchitis and in smokers was mainly observed after the age of 50 years, with gender-adjusted odds ratios for standardized residuals of $\mathrm{FEV}_{1.0}$ of less than -2 (relative to never smokers without bronchitis, reference OR 1); for smokers without bronchitis the odds ratio was $1.8(95 \%$ CT 1.2--2.8); for 
Table 7. Bronchitis symptoms and airway obstruction SFEV $_{1.0}\left(\right.$ SFEV $_{1.0}=$ standardized residuals for forced expiratory volume in 1 second)

\begin{tabular}{|c|c|c|c|c|}
\hline \multirow[t]{2}{*}{ Symptom } & \multicolumn{2}{|c|}{ Never smokers $(N=4050)$} & \multicolumn{2}{|c|}{ Ever smokers $(\mathrm{N}=4377$ ) } \\
\hline & Mean & $95 \% \mathrm{Cl}$ & Mean & $95 \% \mathrm{Cl}$ \\
\hline $\begin{array}{l}\text { No cough or phlegm } \\
\text { Cough or phlegm or both, all cases } \\
\text { Chronic bronchitis } \\
\text { Chronic bronchitis, excluded asthma as adult }\end{array}$ & $\begin{array}{r}0.006 \\
-0.100 \\
0.160 \\
0.008\end{array}$ & $\begin{array}{l}-0.026-+0.037 \\
-0.172--0.027 \\
-0.306--0.140 \\
-0.022-+0.038\end{array}$ & $\begin{array}{l}-0.120 \\
-0.432 \\
-0.534 \\
-0.410\end{array}$ & $\begin{array}{l}-0.157--0.082 \\
-0.458-0.377 \\
-0.638-0.430 \\
-0.519-0.300\end{array}$ \\
\hline All & -0.014 & $-0.043-+0.015$ & -0.224 & $-0.255--0.193$ \\
\hline
\end{tabular}

never smokers with bronchitis it was 2.8 (95\% CI 1.1 $6.8)$; and for smokers with chronic bronchitis it was 8.5 (95\% CI 5.1-14.3).

\section{Infections}

Hospital- or physician-treated severe bronchitis or pneumonia ( $N=1173$ ) was significantly associated with livestock production and dusty occupation outside agriculture, but not with full-time farming (table 3 ). The mean standardized residual for $\mathrm{FEV}_{1.0}$ was $-0.342(95 \% \mathrm{CI}$ -0.405 to -0.279 ), indicating airway obstruction in the group.

\section{Discussion}

The occurrence of chronic bronchitis and related symptoms showed an association with worktime on the farm and different types of livestock production. Combinations with livestock production, dusty occupation outside agriculture, and smoking enhanced the risk of chronic bronchitis. The total impact of work exposure factors on the nonsmokers was 2 - to 3 -fold the risk of chronic bronchitis in the least exposed group (part-time, nonsmoking farmers with no livestock or work exposure outside farming).

Chronic bronchitis was associated with reductions in the mean standardized residuals of $\mathrm{FEV}_{1.0}$ of the smokers. Over the age of 50 years, the proportion of persons with significant airway obstruction, defined as standardized residuals of $\mathrm{FEV}_{1.0}$ of less than -2, was associated with chronic bronchitis even among the never smokers (OR 2.8, 1.1-6.8), and it was highly associated with bronchitis among the smokers (OR 8.5, 5.1-14.3).

\section{Study design}

A representative population was selected of farmers with a varying degree of work activity and different production types. External referents would have had little relevance to the study of worktime and production type indicators and selection factors in farming. Another reason for not using external referents was that "unexposed" leference populations comparable to farmers in life-style and socioeconomic status hardly exist. Moreover, selection problems and lack of knowledge on exposure factors in external reference populations can reduce validity in cross-sectional studies (28). The most likely effect of the chosen design would be to lower power in detecting associations with exposure factors (ie, a tendency to find no effect for farming). However, when such associations are found with internal references, as in the present study, the inferential impact regarding the risk factors is greater.

\section{Selection mechanisms}

Traditionally, the healthy worker effect is a problem in cross-sectional studies of working populations in that it leads to an underestimation of associations with work exposure. Retired farmers were included in the present study. There were associations between "chronic bronchitis" and change in production because of dust problems (OR 3.27, 95\% CI 2.01-5.3) and retirement (OR $2.2,95 \%$ CI $1.6-3.2$ ). These findings suggest that, when airway symptoms of importance to the individual occurs, a change in production to less time-consuming and "exposed" types (ie, from livestock production to no livestock) might tend to reduce the associations between bronchitis and livestock production. The calculated average change in the crude odds ratio for livestock with retirement was from 1.25 to 1.34 , and with change in production it was from 1.25 to 1.40 , indicating a moderate effect on the associations. But the estimated change in production was conservative, as it was based on the change in production to no livestock for 20 persons with bronchitis in 25 years. If the number is set at 40 persons $(70 \%$ of the calculated number of bronchitis with change in production because of dust during 25 years), the crude odds ratio would have changed from 1.25 to 1.88 .

\section{Confounding and effect modification}

No confounding of importance was found in the relations between the outcome variable "chronic bronchitis symptoms" and the exposure variable of full-time farming versus part-time farming, work exposure outside agriculture and tobacco smoking, as the odds ratios were not altered substantially after adjustment for all the risk factors and possible confounders (table 3). The odds ratios did not change substantially with the removal of any of the factors. The combinations of overlapping exposure factors were likely to dilute the bivariate associations 
(table 3). This effect can be avoided with a loss of some statistical power in the "nominal" stratifications of the single and combined factors (tables 4 and 5), but the loss is justified if the models are stable $(26,27)$.

For part-time farming dust exposure outside agriculture and livestock gave a lower odds ratio for chronic bronchitis (OR 1.59) versus no livestock (OR 2.27) (table 4), and nearly the same odds ratio as found for parttime farming with livestock, but without dust exposure outside farming (OR 1.52). The same tendency was observed for "cumulated cough and phlegm" for the fulltime farmers with dust exposure outside farming (no livestock OR 2.56, livestock OR 2.33). Farmers without livestock, as well as part-time farmers, may have more actual work exposure outside farming than farmers with livestock or full-time farming. This possibility may explain the lack of a consistent tendency towards an enhanced effect for livestock and dust outside farming when combined.

Smoking enhanced the effects of the other factors and gave higher risks for chronic bronchitis. However, table 5 indicates independent effects of smoking and livestock but an interaction between smoking and dust outside agriculture.

The effects of current smoking on chronic bronchitis (table 3) were stronger than those of ever smoking (tables 4 and 5), due to the reduced effect among former smokers, as shown previously by Fletcher (29).

The differences between the different livestock production types and combinations of livestock types (table 6) must be interpreted with some caution because the small numbers of cases in some of these groups may have given unstable odds ratios.

\section{Other studies in farming populations}

A population study of 12000 full-time farmers in Finland showed an overall prevalence of chronic bronchitis of $8.2 \%$ in livestock production and $5.6 \%$ in grain production (RR 1.5), and there were no effects of socioeconomic or educational factors within the population $(20$, 21). A Danish study including 1685 part-time and fulltime farmers found a prevalence of chronic bronchitis varying from $4 \%$ to $39 \%$, with smoking (OR 2) and swine production (OR 1.5) as the most important risk factors and grain and dairy production with less risk for chronic bronchitis (19).

Studies of groups of farmers and referents in other parts of the world have shown that livestock production may be considered a risk factor for chronic bronchitis $(15-20,30,31)$. Thus the results of our study are well in agreement with those of the epidemiologic population surveys of farmers in Finland $(21,22)$ and Denmark (19), as well as of smaller studies from other parts of the world $(10,15-18,30,31)$. None of the studies have considered worktime as a separate risk factor.

\section{General population studies}

Two major general population studies of respiratory symptoms and lung function have been performed in Norway during the last 20 years. The first study of the urban population of Oslo $(\mathrm{N}=17000)(8)$, which did not take occupation into consideration, found a prevalence of "chronic bronchitis" of $7 \%$ for the women ( $44 \%$ current smokers) and $12 \%$ for the men (56\% smokers). The other was a study of a mixed urban and rural or coastal population in Hordaland County in western Norway in $1986(\mathrm{~N}=5600)$. It used a questionnaire and job titles for classifying exposure, and it did not consider agriculture as a risk factor for bronchitis (7). The overall prevalence of chronic cough (cough more than 3 months a year during the last 2 years) was $9 \%$; the prevalence of current smoking was $42 \%$ for the men and $35 \%$ for the women. The prevalence of past or present gas or dust exposure was $46 \%$ for the men and $12 \%$ for the women (age 15-70 years). The odds ratio for gas or dust exposure was 1.8 (95\% CI 1.4-2.2) (adjusted for smoking, age and gender); this association is nearly the same as that between chronic bronchitis and dusts or gases in our study (OR 2-2.4 relative to part-time farming with no dusty occupation outside farming). Moreover, the high prevalences of smoking and airway exposure in Hordaland (7) indicate that one should be cautious using general populations as reference groups for farmers. But the lowest exposed groups among our farmers and among the general population of Hordaland had comparably low prevalences of chronic bronchitis, a finding indicating that farmers with low exposure can be preferable as references.

The association with dust exposure outside agriculture in our study was of the same order of magnitude as with occupational exposure for dust or gases in population studies in other parts of the world $(6,32,33)$, although the prevalences of chronic bronchitis may not be directly comparable.

Studies of general populations have shown an excess risk of developing airway disease in occupations with exposure to dust or gases $(6,7,13,32,33)$. As we have shown, 30-40\% of farming men may be engaged in such occupations outside agriculture during parts of their lives.

\section{Concluding remarks}

Chronic bronchitis and related symptoms in farmers were positively associated with the exposure time variable of full-time farming versus part-time farming and even with years of farming for the never smokers. Moreover, chronic bronchitis was associated with the exposure factors livestock production, dust exposure outside farming, and tobacco smoking. The results indicate that work exposure in agriculture and other occupations, as well as 
smoking and combinations of these factors, enhance the risk for chronic bronchitis and associated symptoms in farmers from 2- to 6-fold. Over the age of 50 years, chronic bronchitis was a risk factor for airway obstruction for the never smokers (OR 2.8, 95\% CI 1.1-6.8) and even more so for the smokers (OR 8.5, 95\% CI 5.114.3).

\section{Acknowledgments}

We thank the farmers for participating in the study and the National Health Screening Service of Norway for its professional assistance in the performance of the study. Associate professors Sven Ove Samuelsen and Tor Haldorsen and Professor Petter Laake, Mathematical Institute, University of Oslo, Norway, provided statistical advice. Professor Tor Norseth and Dr Helge Kjuus, National Institute of Occupational Health, Oslo, Norway, offered their advice during the preparation of the manuscript.

The project was economically supported by the Agricultural Research Board of Norway, as well as by the following institutions: The Agricultural Investment Fund, Norske Meierier (Norwegian Dairies), Gjensidige (Insurance) and Forenede (Insurance). The study was approved by The Data Inspectorate and the Regional Medical Ethics Board.

\section{References}

1. Lacey J, Crook B. Fungal and actinomycete spores as pollutants of the workplace and occupational allergens [review]. Ann Occup Hyg 1988:32:515-33.

2. Donham KJ. Hazardous agents in agricultural dusts and methods of evaluation. Am J Ind Med 1986;10:205-20.

3. Kotimaa MH, Oksanen L, Koskela P. Feeding and bedding materials as sources of microbial exposure on dairy farms. Scand J Work Environ Health 1991;17:117-22.

4. Rylander R. Organic dusts and lung disease: the role of inflammation. Amn Agric Environ Med 1994;1:7-10.

5. Rylander R. Lung diseases caused by organic dusts in the farm environment. Am J Ind Med 1986;10:221—227.

6. Lebowitz MD. Occupational exposures in relation to symptomatology and lung function in a community population. Environ Res 1977;14:59-67.

7. Bakke, PS. Obstructive airway diseases and occupational airborne exposure: prevalences and risk factors in a Norwegian community [dissertation]. Bergen: University of Bergen, 1991.

8. Gulsvik, A. Obstructive lung disease in an urban population [dissertation]. Oslo: Department of Lung Diseases, The National Hospital, University of Oslo, 1979.

9. Huhti E. Prevalence of respiratory symptoms, chronic bronchitis and pulmonary emphysema in a Finnish rural population: field survey of age group 40-64 in the Harjavalta area. Acta Tuberculos Scand 1965;suppl 61:1-111.
10. Medical Research Council's Committee on the Aetiology of Chronic Bronchitis. Standardized questionnaires on respiratory symptoms. BMJ 2;1960;1665.

11. American Thoracic Society. Chronic bronchitis, asthma and pulmonary emphysema: a statement by the committee of diagnostic standards for nontuberculous respiratory diseases. Am Rev Respir Dis 1962;85:762-9.

12. Korn RJ, Dockery DW, Speizer FE, Ware JH, Ferris BG Jr. Occupational exposures and chronic respiratory symptoms: a population based study. Am Rev Respir Dis 1987;136:298304.

13. Krzyzanowski M, Kauffmann F. The relation of respiratory symptoms and ventilatory function to moderate occupational exposure in a general population: results from the French PAARC study of 16000 adults. Int J Epidemiol 1988;17:397.

14. Lebowitz MD. The trends in airway obstructive disease morbidity in the Tucson epidemiological study. Am Rev Respir Dis 1989;140:s35-41.

15. Dalphin JCH, Didier P, Dubiez A, Debieuvre D, Allemand H, Depierre A. Etiologic factors of chronic bronchitis in dairy farmers: case control study in the Doubs region of France. Chest 1993;103:417-21.

16. Zejda JE, Hurst TS, Rhodes CS, Barber EM, McDuffie HM, Dosman JA. Respiratory health of swine producers: focus on young worker's. Chest 1993;103:702-9.

17. Dosman JA, Graham BL, Hall D, Punham P, McDuffie $H$ Luchewicz M, et al. Respiratory symptoms and alterations in pulmonary function tests in swine producers in Saskatchewan: results of a survey of farmers. J Occup Med 1988;30:715-20.

18. Katila, M. Respiratory disease in a farming population: a seroepidemiological survey of farmers lung and chronic nonspecific lung disease among dairy farmers in eastern Finland [dissertation]. Kuopio (Finland): Department of Clinical Microbiology, University of Kuopio, 1979.

19. Iversen, M. Respiratory symptoms, allergy, and lung function in farmers: clinical and epidemiological studies [dissertation]. Aarhus (Denmark): Department of Respiratory Diseases, University Hospital of Aarhus, 1992.

20. Terho E, Husman K, Vohlonen I. Work-related respiratory diseases among Finnish farmers. Eur J Respir Dis 1987;71 suppl 152:29-36.

21. Vohlonen I, Tupi K, Terho EO, Husman K. Prevalence and incidence of chronic bronchitis and farmers lung with respect to the geographical location of the farm and to the work of farmers, Eur J Respir Dis 1987;7 I suppl 152:37 46.

22. Terho EO. Work-related respiratory disorders among Finnish farmers. Am J Ind Med 1990;18:269-72.

23. American Thoracic Society. Standardization of spirometry —1987 update. Am Rev Respir Dis 1987;136:1285-98.

24. Bakke P, Gulsvik A, Eide GE, Hanoa R. Smoking habits and lifetime occupational exposure to gases or dusts, including asbestos and quartz, in a Norwegian community. Scand $J$ Work Environ Health 1990;16:195-202.

25. SPSS Inc. Statistical Package for the Social Sciences. Chicago (IL): SPSS Inc, 1990

26. Rothman KJ. Modern epidemiology. Boston (MA): Little Brown \& Co, 1989:299-304.

27. Hosmer DW, Lemeshow S. Applied logistic regression. New York (NY): John Wiley and Sons, 1989:82-144.

28. Checkoway H, Pearce N, Crawford-Brown DJ. Research methods in occupational epidemiology. New York, Oxford: Oxford University Press, 1989.

29. Fletcher C, Peto R, Tinker C, Spizer FE. The natural history of chronic bronchitis and emphysema. Oxford: Oxford Universi- 
ty Press; 1976:106-21.

30. Cormier Y, Boulet L-P, Bedard G, Tremblay G. Respiratory health of workers exposed to swine confinement buildings only or to both swine confinement buildings and dairy barns. Scand $\mathcal{J}$ Work Environ Health 1991;17:269-75.

31. Donham K, Zavala DC, Merchant JA. Respiratory symptoms and lung function among workers in swine confinement buildings: a cross-sectional epidemiological study. Arch Environ Health 1984;39:96-101.

32. Heederik D, Powels H, Kromhout H, Kromhout D. Chronic nonspecific lung disease and occupational exposures estimated by a job exposure matrix: the Zutphen study. Int J Epidemiol 1989;18:382-9.

33. Viegi G, Prediletto R, Paoletti P, Carrozzi L, Di Pede F, Vellutini $M$, et al. Respiratory effects of occupational exposure in a general population sample in north Italy. Am Rev Respir Dis 1991;143:510-5.

Received for publication: 11 June 1996 